\title{
MODIFIKASI DISTRIBUSI MASSA PADA SUATU OBJEK SIMETRI BOLA
}

\author{
Yuant Tiandho \\ Jurusan Fisika, Universitas Bangka Belitung \\ Email: yuanttiandho@gmail.com
}

\begin{abstract}
Abstrak
Umumnya, untuk menggambarkan distribusi massa sebagai fungsi ruang dilakukan pemisahan untuk kondisi di luar dan di dalam objek. Di dalam makalah ini, kami mengusulkan suatu distribusi massa yang berlaku pada kedua kondisi tersebut sehingga tidak perlu dilakukan pemisahan. Jika fungsi tersebut digunakan dalam proses komputasi atau simulasi diharapkan dapat memperingkas algoritma. Fungsi distribusi massa diturunkan berdasarkan fungsi distribusi Fermi-Dirac untuk faktor Boltzman yang bernilai sangat kecil. Adapun objek yang ditinjau adalah objek yang memenuhi sifat simetri bola tetapi tidak menutup kemungkinan dapat diperluas pada sebarang bentuk objek. Melalui fungsi distribusi massa tersebut dapat diturunkan gaya gravitasi, medan gravitasi, dan potensial gravitasi pada sebarang titik tinjau yang bernilai sama dengan tinjauan konvensional. Dengan analogi gaya gravitasi dan elektrostatis maka fungsi distribusi massa tersebut juga dapat diperluas untuk distribusi muatan listrik.
\end{abstract}

Kata Kunci: Gravitasi, Elektrostatik, Mekanika klasik.

\section{PENDAHULUAN}

Sejauh ini, fisikawan meyakini bahwa alam semesta disusun oleh empat gaya fundamenal: gravitasi, elektromagnetik, nuklir lemah, dan nuklir kuat (Ciufolini. Dkk, 2013). Diantara gaya-gaya tersebut, gaya gravitasi merupakan interaksi yang sudah sejak lama dipelajari. Ketertarikan pada pergerakan bendabenda langit, pasang surut air laut, serta gerak jatuh suatu benda adalah beberapa alasan untuk mempelajarinya.

Robert Hooke adalah ilmuwan era Newton yang mengusulkan hukum gravitasi (Gregory, 2006),

$$
F=-\frac{G M m}{r^{2}},
$$

dimana $G$ adalah suatu konstanta gravitasi yang nilainya pertama kali ditentukan oleh Cavendish pada 1978 (Giancoli, 2014). Gravitasi 
Yuant Tiandho- Modifikasi Distribusi Massa...

digambarkan sebagai gaya tarikmenarik (ditandai oleh tanda minus) antara dua objek bermassa dan nilainya berbanding terbalik dengan kuadrat jarak antara keduanya. Dengan menggunakan hukum gravitasi tersebut, Newton dapat menjelaskan pergerakan benda planet sesuai hukum Kepler dengan sangat baik. Meski saat ini teori relativitas umum Einstein dapat lebih akurat menjelaskan gravitasi namun hukum gravitasi klasik tersebut masih dapat digunakan untuk menjelaskan berbagai fenomena dengan sangat teliti.

Teori gravitasi yang diusulkan oleh Hooke atau juga sering disebut sebagai gaya gravitasi Newton merupakan salah satu materi pokok yang dipelajari pada mekanika klasik dan fisika dasar. Untuk tinjauan gravitasi dengan objek berdimensi titik, secara umum tidak ditemui kendala yang berarti. Namun untuk tinjauan dengan objek berdimensi (misal bola) seringkali pembahasan gravitasi harus dilakukan pemisahan untuk daerah di dalam objek dan di luar objek (Young dan Freedman, 2012). Penerapan gravitasi di luar objek dapat diselesaikan secara langsung dengan menggunakan massa total, sedangkan untuk bagian dalam objek digunakan persamaan Poisson atau persamaan Gauss untuk gravitasi sesuai dengan massa yang dilingkupi. Selain itu, dalam mendeskripsikan massa juga dilakukan pemisahan. Misalkan untuk objek bola padat, massa selalu dinyatakan dalam dua kondisi sesuai dengan titik tinjau r,

$$
M(r)\left\{\begin{array}{l}
\frac{4}{3} \pi \rho r^{3}, \text { untuk } r<R \\
M, \text { untuk } r \geq R
\end{array}\right.
$$

dimana $\mathrm{R}$ adalah radius objek dan $\mathrm{M}$ adalah massa totalnya.

Sistematika penulisan makalah ini adalah sebagai berikut, pada Bagian 2 kami mengusulkan sebuah persamaan distribusi massa yang berlaku untuk kondisi di dalam dan di luar objek. Dengan demikian, deskripsi massa secara umum dapat ditunjukkan oleh sebuah kondisi tunggal tidak seperti pada pers. (2). Pada Bagian 3, kami menggunakan fungsi distribusi massa tersebut untuk memperoleh paraneter dalam mekanika seperti gaya, medan, dan potensial gravitasi. Hasil yang diperoleh menunjukkan bahwa dengan fungsi distribusi massa yang 
Yuant Tiandho- Modifikasi Distribusi Massa...

kami gunakan memiliki nilai yang sama dengan hasil perhitungan konvensional. Pada Bagian 4, fungsi distribusi massa diperluas untuk kasus kulit bola. Fungsi distribusi muatan tersebut juga dapat diterapkan untuk mempelajari perhitungan elektrostatis

\section{FUNGSI DISTRIBUSI MASSA}

Untuk memperoleh fungsi distribusi massa yang berlaku di seluruh kondisi kami mencoba beberapa fungsi yang diperkirakan memiliki bentuk yang sesuai dan akhirnya dipilih fungsi distribusi Fermi-Dirac dalam mekanika statistik (Troy, 2012)

$$
f(\varepsilon)=\frac{1}{\exp \left[\frac{\varepsilon-\mu}{k T}\right]+1}
$$

Hal yang menarik dari fungsi distribusi Fermi-Dirac adalah dapat diperoleh suatu grafik dengan tingkat perubahan yang cukup drastis apabila faktor kT dalam eksponensial bernilai kecil (Kittel, 2005). Sifat itulah yang kelak dibutuhkan untuk menggambarkan distribusi massa suatu objek.
Dengan memodifikasi fungsi distribusi Fermi-Dirac pada pers. (3) maka kami mengusulkan bahwa fungsi distribusi massa memiliki bentuk,

$$
M(r)=\lim _{\alpha \rightarrow \infty}\left(\frac{4 \pi \rho r^{3}}{3(1+\exp [\alpha(r-R)])}+\frac{M_{R}}{1+\exp [\alpha(R-r)]}\right)
$$

dimana $M(r)$ adalah massa pada titik tinjau $r, \rho$ adalah massa jenis objek, $R$ adalah radius objek, dan $\mathrm{M}_{\mathrm{R}}$ adalah massa pada titik tinjau $\mathrm{R}$ atau massa totalnya. Pemilihan nilai $\alpha$ sebagai limit tak hingga bertujuan untuk memperoleh nilai massa seperti yang diharapkan dan analogi dengan faktor kT pada persamaan Fermi-Dirac yang bernilai sangat kecil. Suku pertama dalam fungsi distribusi massa tersebut menggambarkan kondisi untuk daerah dan akan lenyap pada daerah . Sebaliknya, pada daerah massa objek diberikan oleh suku yang kedua. Dengan demikian, kondisi di dalam dalam dan di luar objek bermassa dapat didefinisikan oleh satu bentuk fungsi distribusi massa saja.

Pada objek dengan $M_{R}=1, R=1$, dan $\rho=3 /(4 \pi)$, distribusi massanya 
diberikan oleh Gambar 1. Pada kurva tersebut tampak bahwa untuk daerah , massa objek bertambah seiring jarak tinjau $r$ dan untuk daerah tampak bahwa massa objek bernilai konstan.

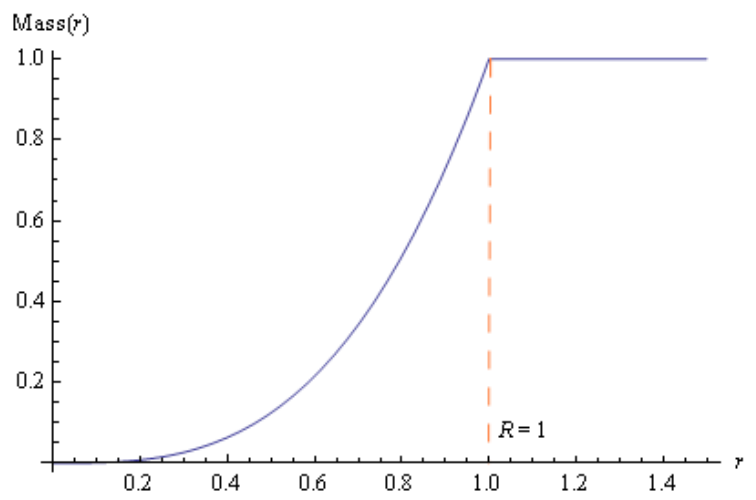

Gambar 1. Fungsi distribusi massa suatu objek dengan massa $M_{R}=1$ dan radius
Hal ini sesuai dengan kondisi massa pada pers. (2) yang memisahkan definisi massa untuk daerah dan daerah .

$$
R=1 .
$$

\section{MEKANIKA GRAVITASI}

Mekanika gravitasi sangat erat hubungannya dengan gaya gravitasi, medan gravitasi, dan potensial gravitasi. Persoalan itulah yang menjadi acuan utama dalam mempelajari teori gravitasi klasik. Pada umumnya, untuk menentukan gaya gravitasi suatu objek bermassa pada sebarang titik, selalu dibutuhkan definisi apakah titik tinjau berada di dalam objek atau di bagian luarnya. Apabila tinjauan berada pada bagian luar, maka gaya gravitasi dapat ditentukan dengan mudah sesuai pers. (1), tetapi jika tinjauan dilakukan pada bagian dalam, maka gaya gravitasi dengan massa uji $\mathrm{m}$ diberikan oleh,

$$
F=-\left(G \rho \frac{4 \pi m}{3}\right) r
$$

Suku dalam kurung adalah sebuah konstanta. Sehingga gaya di daerah tersebut sebanding dengan pergeseran r secara linier dan analogi dengan gerak harmonik sederhana.

Sebagai perbandingan, apabila diterapkan distribusi massa secara umum seperti pada pers. (4), maka hanya dibutuhkan sebuah persamaan gaya yang berlaku untuk semua daerah, 


$$
F(r)=-\frac{G m}{r^{2}} \lim _{\alpha \rightarrow \infty}\left(\frac{4 \pi \rho r^{3}}{3(1+\exp [\alpha(r-R)])}+\frac{M_{R}}{1+\exp [\alpha(R-r)]}\right)
$$

Pada daerah suku kedua dalam didefinisikan konstanta $G=1$ pers. (6) akan lenyap dan hanya menggunakan pers. (6), dapat dilihat tersisa suku pertama saja tetapi pada Gambar 2. Tampak dengan jelas sebaliknya, pada daerah suku bahwa untuk gaya gravitasi akan pertama akan lenyap dan hanya meningkat secara linier terhadap $\mathrm{r}$ dan tersisa suku kedua saja. Adapun ketika, gaya gravitasi menurun secara grafik gaya terhadap sebarang titik kuadratik seiring dengan pertambahan tinjau $r$ untuk suatu objek dengan $M_{R} \quad r$. $=1, \mathrm{R}=1$, muatan uji $\mathrm{m}=1$ dan

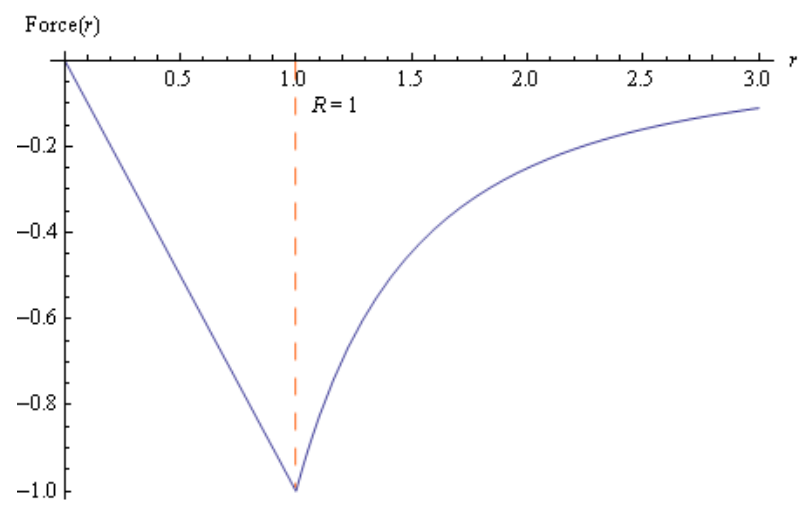

Gambar 2. Grafik gaya terhadap titik tinjau $r$ dengan massa $M_{R}=1$, radius $R=1$, dan massa uji $m=1$.

Untuk memperoleh nilai medan menggunakan hubungan antara gravitasi dapat dilakukan dengan medan gravitasi dan gaya gravitasi,

$$
g(r)=-\frac{G}{r^{2}} \lim _{\alpha \rightarrow \infty}\left(\frac{4 \pi \rho r^{3}}{3(1+\exp [\alpha(r-R)])}+\frac{M_{R}}{1+\exp [\alpha(R-r)]}\right)
$$

Dari hubungan tersebut dapat terhadap sebarang titik tinjau seperti dibentuk grafik medan gravitasi pada Gambar 3. Sama seperti gaya 
gravitasi, medan gravitasi juga akan meningkat secara linier pada daerah dan akan meluruh secara kuadratis untuk daerah. Secara ringkas, berdasarkan perbandingan antara nilai $\mathrm{r}$ dan $\mathrm{R}$ dalam pers. (7) dapat diperoleh nilai persamaan medan $g(r)=\left\{\begin{array}{l}-\left(\frac{4 \pi G \rho}{3}\right) r, \text { untuk } r<R \\ -\frac{G M_{R}}{r^{2}}, \text { untuk } r \geq R\end{array}\right.$ gravitasi sebagai,

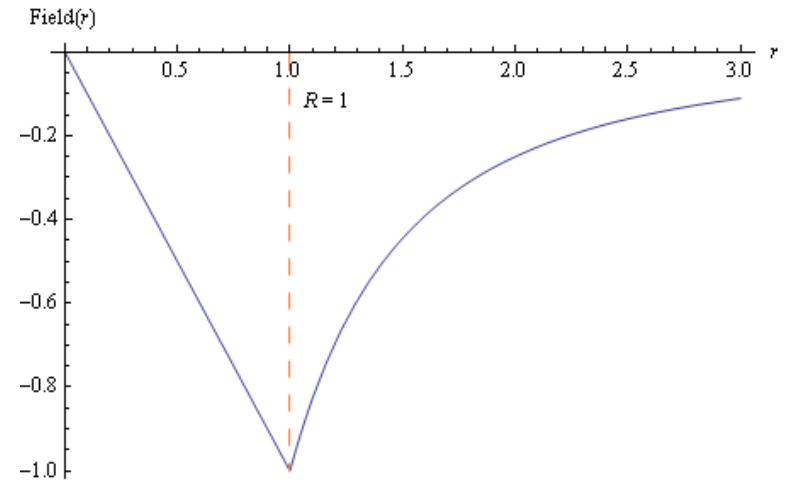

Gambar 3. Grafik medan gravitasi terhadap titik tinjau $r$ dengan massa $M_{R}=1$, radius $R=1$.

Gambar 3. Grafik medan gravitasi terhadap titik tinjau $r$ dengan massa $\mathrm{MR}=1$, radius $\mathrm{R}=1$.

Potensial gravitasi didefinisikan,

$$
V(r)=-\int_{\infty}^{r} g d r
$$

Integrasi tersebut lebih mudah dilakukan apabila diketahui daerah mana yang ingin ditentukan potensialnya. Pada daerah dapat digunakan medan gravitasi sesuai pers. (8). Dengan sedikit memanipulasi batas integrasi maka dan hasil tersebut sesuai dengan hasil yang diperoleh melalui persamaan Gauss untuk gravitasi. 
Yuant Tiandho- Modifikasi Distribusi Massa...

potensial pada sebarang titik tinjau ditunjukkan oleh Gambar 4. Tampak bahwa untuk tinjauan setelah melewati radius objek, dalam hal ini $\mathrm{R}=1$, terjadi perubahan bentuk kurva dari yang awalnya kuadratik menjadi

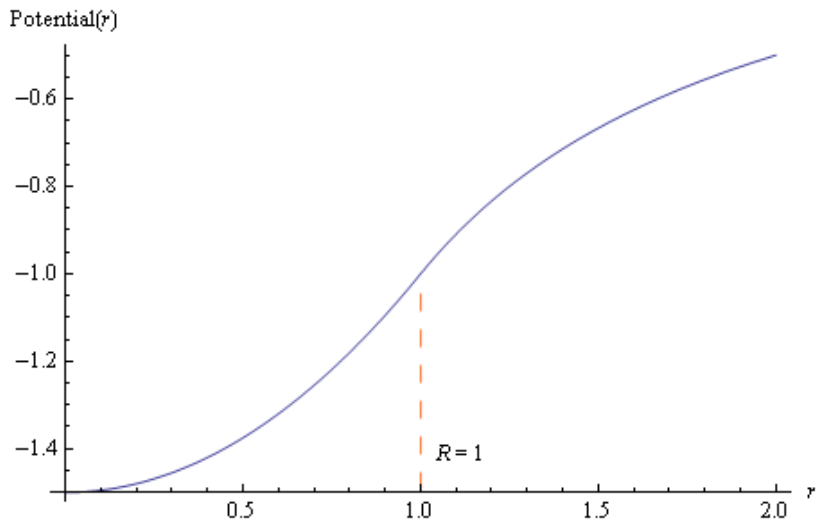

Gambar 4. Grafik potensial gravitasi terhadap titik tinjau $r, M_{R}=1$, dan radius

$$
R=1
$$

berbanding terbalik dengan titik tinjau. Tentu saja hal ini terjadi akibat distribusi potensial yang berbeda antara potensial di dalam objek dengan potensial di luar objek.
KASUS PADA KULIT BOLA

Pembahasan yang telah dilakukan pada Bagian 2 dan 3 mengasumsikan objek yang ditinjau memiliki bentuk berupa bola padat dengan rapat massa bernilai konstan. Lalu bagaimana untuk objek yang memiliki bentuk serupa kulit bola? Bentuk ini menarik karena dengan melakukan tinjauan pada kasus ini dapat disusun sebuah model untuk distribusi muatan pada konduktor. Karena seperti diketahui, muatan konduktor hanya tersebar pada bagian permukaannya saja. Dengan demikian, diharapkan persamaan fungsi distribusi massa tidak hanya berlaku untuk massa saja melainkan dapat diperluas untuk objek bermuatan.

Apabila massa atau muatan hanya tersebar pada bagian permukaan bola maka massa jenis di dalam $\rho=0$. Sehingga fungsi distribusi massa mereduksi menjadi suku keduanya saja.

$$
M(r)=\lim _{\alpha \rightarrow \infty}\left(\frac{M_{R}}{1+\exp [\alpha(R-r)]}\right)
$$

Adapun grafik distribusi massanya ditunjukkan oleh Gambar 5. Pada 
grafik tersebut tampak bahwa untuk benda kemudian untuk bernilai daerah massa bernilai nol dan secara konstan. signifikan meningkat pada radius

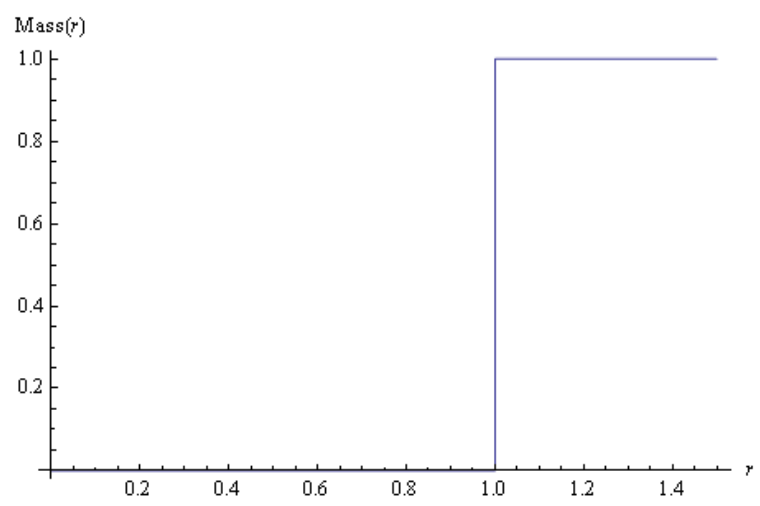

Gambar 5. Grafik distribusi massa kulit bola terhadap titik tinjau $r$ dengan massa $M_{R}=1$, radius $R=1$.

Adapun medan gravitasi pada kulit bola adalah,

$$
E(r)=-\lim _{\alpha \rightarrow \infty}\left(\frac{G M_{R}}{(1+\exp [\alpha(R-r)]) r^{2}}\right)
$$

dan plot grafiknya dapat dilihat pada Gambar 6. Melalui hasil tersebut tampak dengan jelas bahwa medan gravitasi di dalam kulit bola bernilai nol. Dengan kata lain, gaya gravitasi di dalam kulit bola juga bernilai nol. Medan gravitasi mulai muncul dipermukaan atau di radius bola dan menurun secara kuadratik setelahnya.

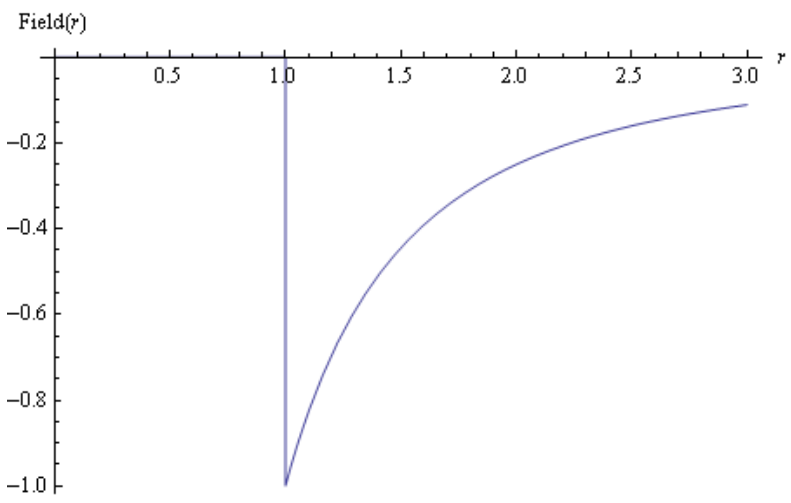

Gambar 6. Grafik medan gravitasi kulit bola terhadap titik tinjau $r$ dengan

$$
\text { massa } M_{R}=1 \text {, radius } R=1 \text {. }
$$


Karena medan gravitasi dalam

Dari hasil-hasil yang telah kami kulit bola adalah nol maka dari pers. peroleh mulai dari fungsi distribusi (9) dapat dinyatakan bahwa potensial massa untuk bola padat hingga kulit gravitasi di dalam kulit bola bernilai bola semuanya sesuai dengan yang konstan. Potensial gravitasi di daerah tercantum pada buku-buku mekanika dapat ditentukan dengan klasik dan fisika dasar [2, 3, 4, 5, 8]. menggunakan pers. (13) dan Selain itu, dengan membandingkan diperoleh hasil yang sama dengan hasil yang pada Gambar 5, 6, dan 7 pers. (11). Melalui nilai potensial dengan distribusi muatan, medan gravitasi pada permukaan kulit bola listrik, dan potensial listrik pada bola maka dapat ditentukan potensial di dalam kulit bola sebagai,

$$
V_{\text {dalam }}=-\frac{G M_{R}}{R}
$$

dan grafik potensial pada sebarang titik tinjau untuk kulit bola diberikan oleh Gambar 7.

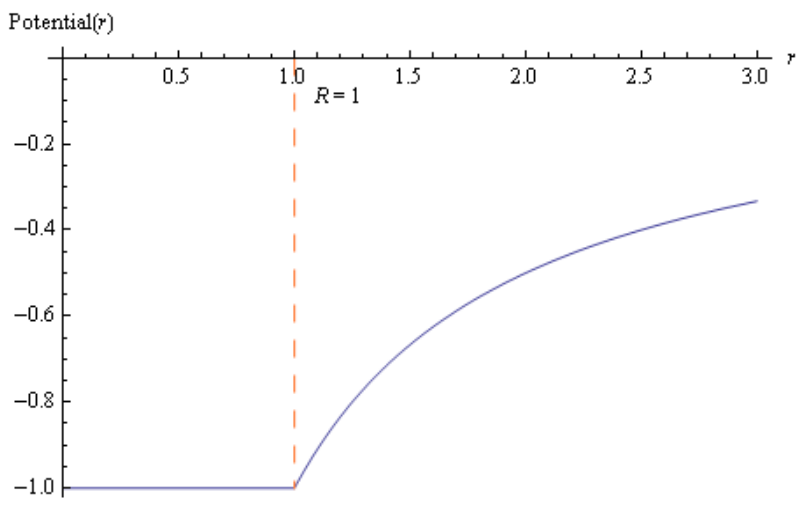

Gambar 7. Grafik potensial gravitasi kulit bola terhadap titik tinjau r dengan massa $\mathrm{MR}=1$, radius $\mathrm{R}=1$.

\section{KESIMPULAN}

Dengan melakukan modifikasi fungsi distribusi Fermi-Dirac dapat diturunkan fungsi distribusi massa yang berlaku untuk daerah di dalam objek dan di luar objek. Penggunaannya dalam mekanika gravitasi seperti untuk menentukan 
gaya gravitasi, medan gravitasi, dan potensial gravitasi menunjukkan bahwa hasil tersebut sesuai dengan referensi. Tinjauan pada kulit bola juga memperoleh hasil yang memuaskan sehingga fungsi distribusi massa tersebut dapat diaplikasikan untuk menggambarkan distribusi muatan pada konduktor.

\section{DAFTAR PUSTAKA}

Ciufolini, I, dkk. 2013. "Fundamental physics and general relativity with the LARES and LAGEOS satellites," Nuclear Physics B, vol. 243, pp. 180-193.

Giancoli, D. C. 2014. Physics Principles with Applications, USA: Pearson Eduaction, Inc.

Gregory,R. D. 2006 Classical Mechanics, New York: Cambridge University Press.

Griffiths, D. J. 1999. Introduction to Electrodynsmics, New Jersey: Prentice-Hall, Inc.

Kittel,C. 2005. Introduction to Solid State Physics, USA: John Wiley \& Sons, Inc.

Troy, W. C. 2012. "Low temperature properties of the Fermi-Dirac, Boltzmann and Bose-Einstein equations," Physics Letters A, vol. 376, pp. 2887-2893.

Young, H. D. dan Freedman, R. A. 2012. Sears and Zemansky's University Physics: with Modern Physics, San Fransisco: AddisonWesley 